\title{
Premium Private Labels Products: Drivers of Consumers' Intention to Buy
}

\author{
Elisa Martinelli ${ }^{1} \&$ Francesca De Canio ${ }^{1}$ \\ ${ }^{1}$ Department of Economics “Marco Biagi”, University of Modena and Reggio Emilia, Modena, Italy \\ Correspondence: Elisa Martinelli, Department of Economics "Marco Biagi”, University of Modena and Reggio, \\ Viale Berengario, 51 - 41121 Modena, Italy. E-mail: elisa.martinelli@unimore.it
}

Received: June 18, 2019

Accepted: July 20, 2019

Online Published: August 5, 2019

doi:10.5539/ijbm.v14n9p36

URL: https://doi.org/10.5539/ijbm.v14n9p36

\begin{abstract}
In the last years, there has been a proliferation of Private Labels (PLs) and a strategic change in the way retailers conceive and manage this kind of tool. From an instrument devoted to underline the price convenience orientation of retailers, today PLs are articulated in different tiers (economy, standard and premium) and have become a tool to give a good quality option to customers, improving their loyalty and differentiating from competitors. In this context, the paper focuses on a specific PLs tier, Premium Private Labels (PPLs), given the high growth rates, current and perspective, they present. Specifically, the study aims at investigating the drivers of PPLs consumer buying intention. Results derived by the Structural Equation Model employed on a dataset of 211 questionnaires collected by administering a survey on a sample of actual buyers of PPL products show that perceived product quality, label consciousness and the PPL familiarity exert a positive impact on attitude towards PPL products. Conversely, retail customers do not choose a PPL product to conform to others. Moreover, although the increasing extension of the PPL assortment with Geographical Indications, no significant effect was found between the PPLs products branded with a PDO/PGI (Protected Designation of Origin/Protected Geographical Indication) label and attitude towards PPLs. Finally, findings show that the higher the level of consumer familiarity to the PPL, the higher the intention to buy PPL products. These results offer relevant implications from a marketing and strategical viewpoint, providing valuable insights for practitioners and scholars.
\end{abstract}

Keywords: premium private labels, geographical indication, label consciousness, conformism, PPL familiarity, structural equation modelling

\section{Introduction}

Private labels (PLs), or store brands or own brands, are any brand owned (and seldom produced) by the retailer and offered in its outlets only (Morris, 1979). Traditionally, these products have been considered as low price/good value for money offerings, especially present in food categories, as for the perceived quality differential with NBs (Richardson et al., 1994). Recently PLs have gone through a market upgrade, as retailers heavily invested on them, defining a multi-tiered segmentation of PL products - economy, standard and premium (Ter Braak et al., 2014). Between these tiers, the premium one results to be highly interesting and attractive, given the high growth rates it presents, the good margins it assures to retailers (Ter Braak et al., 2013) and the resulting impact from the competitive point of view. Due to these positive results, and to the growing importance gained in retailers' strategies, PPLs were defined as the "Holy Grail" of retailers (Pauwels \& Srinivasan, 2009, p.279), as well as "the hottest trend in PL retailing" (Kumar \& Steenkamp, 2007, p. 41). As shown in the literature, the positioning of the PPL is very different from that of the standard PL (Sethuraman \& Gielens, 2014): if the latter tends to imitate the quality of industrial brands (Geyskens et al., 2010) and is sold at a price lower than $20-30 \%$ (Steenkamp et al., 2010), the PPL has instead quality and price similar or superior to the premium NB (Geyskens et al., 2010). Therefore, these are PL lines aimed at satisfying specific customer targets and / or differentiated demand needs. Consumers' perceptions, their purchasing behavior and their buying drivers must therefore be investigated from scratch, as they are specific to this type of PL tier (ter Braak et al., 2014).

Sethuraman (2009) underlined the importance of performing empirical research on the conditions that support the introduction of premium-level of PL products. In fact, the private label literature is rich in studies on drivers influencing the introduction of standard PLs (among others: Raju et al., 1995; Sayman \& Raju, 2004) and which 
explain their market implications (Dhar \& Hoch, 1997; Steenkamp \& Geyskens, 2014), while it is not clear if the results obtained can be applied to PPLs and to what extent (ter Braak et al., 2014). As Walsh and Mitchell (2010, p. 4) stated "now that the market for PLB is maturing and any retailers are offering premium PLB that compete directly with national brands on the basis of quality and branding to attract a different segment of the market, research needs to look at other explanatory variables that might explain consumers' intention to buy private label brands". Within this context, the present study aims at contributing to the scientific knowledge on consumer behaviour regarding PPLs, verifying the effect of some drivers of the intention to purchase PPL items, with particular reference to: perceived product quality, label consciousness, PPL familiarity, conformism, Geographical Indication (GI). We purpose a structural model aimed at exploring the effect exerted by these drivers on attitude towards the PPL and, in turn, how the latter impacts on consumers' intention to buy the PPL. Our research question is as follows: What are the direct and indirect drivers of consumers' intention to buy a PPL? Accordingly, this paper is expected to contribute to the private label literature by proposing and testing a theoretical model of the direct and indirect antecedents of consumers' intention to buy PPL products. Therefore, we contribute from a managerial viewpoint by showing the drivers supporting retailers' PPL strategies.

\subsection{Premium Private Labels}

PPLs are considered high quality products that retailers are offering in order to differentiate themselves from competitors (Huang \& Huddleston, 2009). According to Soberman and Parker (2006), at an international level the pioneers in the launch of PPLs were, in the early 1990s, the Anglo-Saxon distributors. PPLs brands currently present on the market are the followings: Sainsbury's "Taste the Difference" in the UK, "Wal-Mart's Sam's Choice" in the US, "Carrefour Sélection" in France, "Top" by Esselunga in Italy, etc.

These are PL products of particular refinement and quality, with a price at least in line with that of leading industrial brands (Bazoche et al., 2005; Geyskens et al., 2010; ter Braak et al., 2014) and higher than that of standard branded products. For example, Tesco's "Finest" brand chocolate has a price aligned with that of Lindt chocolate, an industrial premium positioning brand within the category in question. It follows that while the standard PLs are generally considered products intended for consumer segments that pay more attention to value-for-money proposals, PPLs are aimed at consumers who are more sophisticated, attentive to quality and less price sensitive.

The PPL is characterized by a distinctive positioning in virtue of the high-quality level that distinguishes it in terms of raw materials used for its production, care and control employed in the transformation process, origin and organoleptic characteristics, refinement in the packaging and in the distinctive signs characterizing the branding process, allowing retailers to compete with the highest quality industrial brands (Geyskens et al., 2010; Feetham \& Gendall, 2013).

\section{Theoretical Framework and Hypotheses}

In this work, buying attitudes and intentions are measured by the means of several antecedents (see Fig. 1). Purchase intentions stand for "the possibility that consumers will plan or be willing to purchase a certain product or service in the future" (Wu et al. 2011, p.32). Attitude toward PLs corresponds to "a predisposition to respond in a favorable or unfavorable manner due to product evaluations, purchase evaluations, and/or self-evaluations associated with private label grocery products" (Burton et al., 1998, p. 298).

Product quality plays a key role in determining consumer preferences, satisfaction and purchasing decisions for a product (Raju et al., 1990; Zeithaml et al., 1996). This driver has also an effect on the decision-making process to choose the store in which to make purchases (Pan \& Zinkhan, 2006). In the PL literature, a direct relationship between the increase in the perceived quality of the PL and the increase in sales of private label products was verified (Hoch \& Banerji 1993). Moreover, PLs products, and in particular PLs with a higher quality level, play a critical role in determining the level of consumer satisfaction and store loyalty (Binninger, 2008).

Given that the literature has verified that the main reason for the growth of PL products has been found to be their increase in perceived quality (Hoch \& Banerji, 1993), the impact of PPLs perceived quality on attitude towards PPL products is expected to be highly significant and positive, as the following hypothesis posits:

\section{H1: Premium Private Labels perceived quality (PPLQ) significantly and positively influences attitude towards PPLs (PPLA).}

Typical local and regional products are generally referred to as exclusive, high quality and expensive, thus making them particularly suitable for the development of premium brands. These are values towards which the current consumer has become particularly sensitive over the last decade, also in line with a growing anti-globalization sentiment concerning food products that emerged (Parrott et al., 2002). The European Union, 
in order to provide consumers with safer information on the origin and the area of production, supported and pushed the policy of quality certification for agri-food products developing Geographical Indication labels: "EU quality policy aims at protecting the names of specific products to promote their unique characteristics, linked to their geographical origin as well as traditional know-how. Product names can be granted with a 'geographical indication' (GI) if they have a specific link to the place where they are made. The GI recognition enables consumers to trust and distinguish quality products while also helping producers to market their products better." (European Commission, 2019). However, while trademarks are individual property rights, geographical indications are considered as "club goods" (Teuber, 2011, p. 904). The positive effects of the use of a Geographical Indication such as a PDO/PGI label are salient: a lower risk perception thanks to the guarantee offered by the Geographical Indication certification that increases the acceptance level of these products between consumers, given their higher perceived value (Fotopoulos \& Krystallis, 2003). This is why retailers are often employing these kinds of labels to increase the perceived value of their PPLs and stimulate consumers' proneness. As concluded by Morrone and Schena (2019, p. 74) in their work on PLs in Italy, "The connection with territory, above all when the latter is represented by a local food, is another element with a growing consumer demand". Therefore, we believe that exploring the role of a geographical indication for a PPL SKU would help in getting a more comprehensive picture of consumers' attitude towards PPLs. Since typical food products appear to be a key tool used by retailers to characterize PPLs and to activate processes for transferring the elements of security and guarantee that they possess to the customers' perceptions, the second hypothesis that characterizes the proposed model is to verify the following statement:

\section{H2: The Geographical Indication (GI) exerts a significant and positive effect on attitude towards PPLs (PPLA).}

"Eating experiences reveal complex relationship between food and society, involving material and symbolic aspects of cultures, dietary order, but also aesthetics or hedonism" (Boutaud et al., 2016, p.1). Today, above all, typical and local products are experiencing a period of particular success based on the food and cooking media exposure, triggering trends and viral behaviors. In this context, conformist buyers use the buying process as a mean to establish their identity within the group they wish to be associated with (Kastanakis \& Balabanis, 2012; Lascu \& Zinkhan, 1999). Therefore, the study aims to understand if the tendency to conformism connotes the buyer of ef a PPL. The third hypothesis underlying the study is consistently formulated as follows:

\section{H3: The degree of conformism of the buyer (CONF) significantly and positively impacts on attitude towards PPLs (PPLA).}

Food labels are often an important source of information able to help and drive consumers' in their grocery shopping. In a society in which the consumer is increasingly interested in knowing the origin and nutritional aspects of the products he/she consumes (van der Merwe et al., 2013; Dimara \& Skuras, 2005), the purchaser's propensity to read the labels becomes important, particularly when high quality products are involved. In this context, food labels offer pre-purchase information about ingredients, nutrition contents, and health claims, among other information (van der Merwe et al., 2014). Accordingly, we assume that those who pay more attention to and carefully read the label of a product tend to develop a more positive attitude towards the latter. This should be key when a PPL is concerned, as the following hypothesis postulates:

\section{H4: Label Consciousness (LAB) exerts a significant and positive impact on attitude towards PPLs (PPLA).}

During the buying process, consumers base their choice on prior knowledge (Ward et al., 1992). Consumers that possess a richer knowledge of a product category show a more positive attitude towards it (Alba \& Hutchinson, 1987), as well as a stronger intention to buy it (Berger et al., 1994; Grønhaug, Hem \& Lines, 2002). Similarly, in the study conducted by Laroche and colleagues $(1996$, p.120) exploring multiple brands, the authors found that brand knowledge "is a competitive determinant of intention". In fact, when a consumer is familiar with a brand, he/she recalls in his/her mind positive memories and perceptions that influence his/her attitude (Campbell and Keller, 2002). This effect reveals its outcomes even when PLs products are involved. In fact, previous research highlights that the evaluation of private label brand products may be affected by familiarity (Dick et al., 1995). PLs familiarity positively stimulates PLs purchase intention too (Calvo-Porral \& Levy-Mangin, 2016; González-Mieres et al., 2006; Sheau-Fen et al., 2012;), due to the reduction of the perceived risk of buying these retailer brands (Richardson et al., 1996). As the perceived risk should be lower in the case of PPLs due to the higher level of perceived quality possessed, we can postulate the following hypotheses:

H5a: PPL Familiarity (PLLF) has a significant and positive impact on attitude towards PPLs (PPLA). 


\section{H5b: PPL Familiarity (PLLF) has a significant and positive impact on intention to buy PPLs (PPLI).}

The Theory of Planned Behaviour (Ajzen, 1991) suggests that an individual attempts for attitude-behaviour consistency. Specifically, a positive attitude toward the object (i.e., PLs) is a major antecedent of an individual's intention to buy this object. In fact, extant literature has long found a common and shared consensus in considering that the attitude towards a product positively stimulates the intention to buy it (Ajzen \& Fishbein, 1980). This has been verified to happen even when the purchase concerns PLs products (Bhat \& Reddy, 2001), influencing the percentage of private labels purchased (Burton et al., 1998). Consequently, the sixth hypothesis is aimed at verifying this relationship when a PPL is concerned:

H6: A favorable attitude towards PPLs (PLLA) exerts a significant and positive impact on intention to buy PPLs (PPLI).

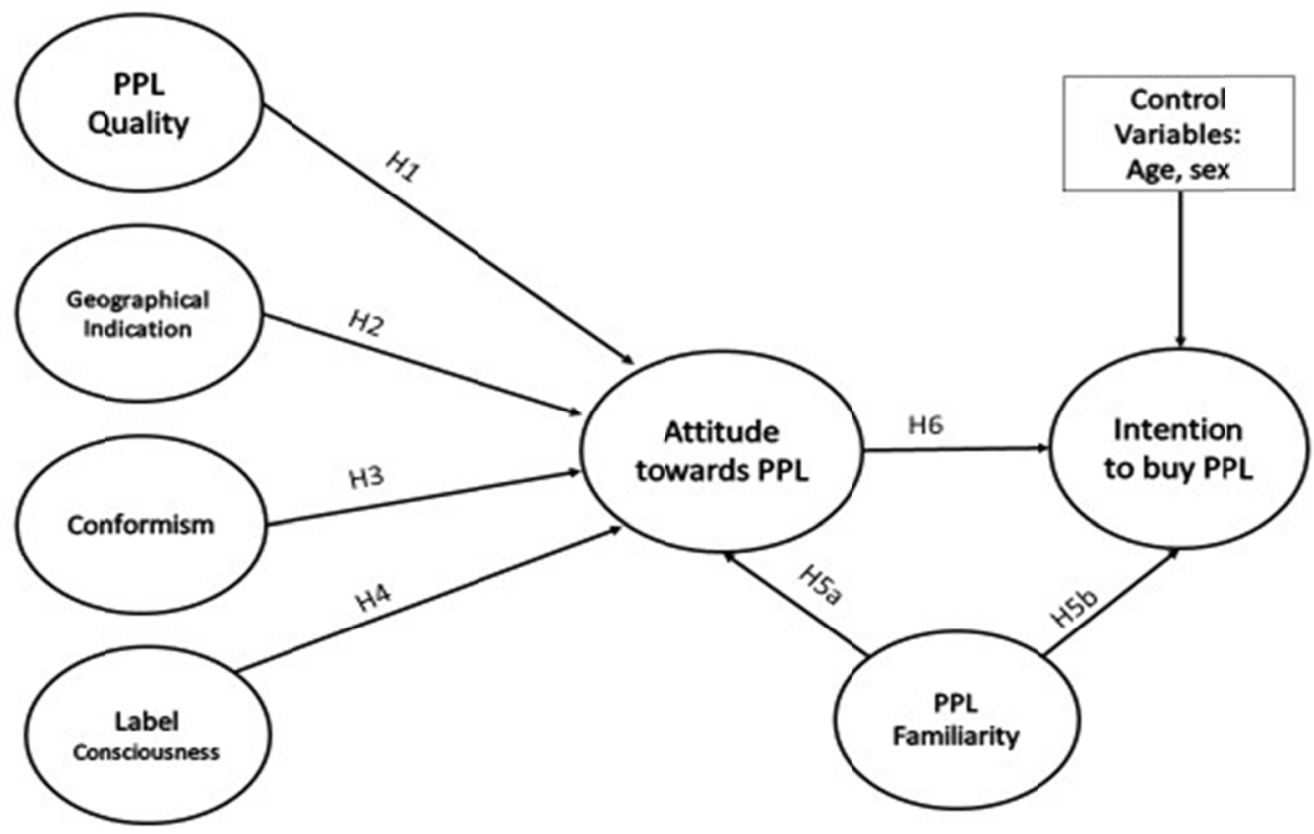

Figure 1. Conceptual model

\section{Method}

To reach the study aims, a survey was performed on a sample of customers of a leading Italian retailer. The latter offers a wide range of PLs and poses a particular emphasis on its Premium tier, which SKUs are mainly labelled with a Geographical Indication. In fact, within the European countries, Italy is the one with the highest number of Geographical Indications (299) (MIPAAF, 2019).

Today, in Italy, PLs represent an important alternative to national brands (NBs), with a market-share of almost $20 \%$ on total Italian sales for a value of $€ 10.3$ billion (Borsa Italiana, 2019). In Italy, PPL products are gaining the best increase within PLs year-over-year (+ 17.9\% in 2017 - IRI, 2018), as well as showing a strong market potential. According to the estimates of The European House - Ambrosetti (2018), PPLs will support the growth of entire range of Pls in the next future, expected to increase from $14 \%$ in 2016 to $22 \%$ in 2020 .

Data was gathered in one supermarket located in North Italy in November 2017. A total of 258 completed questionnaire were gathered from a convenience sample of retail customers, approached as soon as they entered the store, before doing their shopping, by two trained interviewers. The response rate for this survey was $25 \%$ : one person out of four enquired filled in the questionnaire. The final sample was reduced to 211 respondents who declared to be steady PPLs buyers.

\subsection{Measures}

The measures employed were validated scales adapted by the literature and pre-tested (Tab. 1). Interviewees were asked to assess their responses on a 7-point Likert scale $(1=$ strongly disagree and $7=$ strongly agree $)$. 
Table 1. Constructs and measures standardized factor loadings

\begin{tabular}{|c|c|c|c|c|c|}
\hline Original scale & Constructs & Items & & F.L. & T-value \\
\hline \multirow{4}{*}{$\begin{array}{l}\text { adapted from Grewal et } \\
\text { al. (1998) }\end{array}$} & \multirow{4}{*}{$\begin{array}{l}\text { Intention to buy PPL } \\
\text { (PPLI) }\end{array}$} & I will continue to buy the PPL " $\mathrm{X}$ " products & PPLI1 & 0.985 & n.d. \\
\hline & & $\begin{array}{l}\text { I will buy again the PPL " } X " \text { next time I go grocery } \\
\text { shopping }\end{array}$ & PPLI2 & 0.879 & 28.984 \\
\hline & & I am willing to buy again the PPL "X products" & PPLI3 & 0.990 & 52.339 \\
\hline & & The buying of PPL " $\mathrm{X}$ " product is.... & & & \\
\hline \multirow{2}{*}{$\begin{array}{l}\text { adapted from Aaker and } \\
\text { Keller (1990) }\end{array}$} & \multirow{3}{*}{$\begin{array}{l}\text { Attitude towards PPL } \\
\text { (PPLA) }\end{array}$} & Negative/positive & PPLA1 & 0.900 & n.d. \\
\hline & & Useless/useful & PPLA2 & 0.909 & 10.668 \\
\hline \multirow{4}{*}{ DelVecchio (2001) } & & $\mathrm{Bad} / \mathrm{Good}$ & PPLA3 & 0.833 & 9.558 \\
\hline & \multirow{3}{*}{ PPL Quality (PPLQ) } & I think PPL "X" products have a superior quality & PPLQ1 & 0.950 & n.d. \\
\hline & & I think that PPL " $X$ " products are excellent & PPLQ2 & 0.858 & 17.530 \\
\hline & & $\begin{array}{l}\text { Buying a PPL product with a PDO/PGI label guarantee } \\
\text { a constant product quality }\end{array}$ & GI1 & 0.775 & n.d. \\
\hline \multirow[b]{2}{*}{$\begin{array}{l}\text { adapted from } \\
\text { Ittersum et al. (2007) }\end{array}$} & \multirow{2}{*}{$\begin{array}{l}\text { Geographical } \\
\text { Indication (GI) }\end{array}$} & I prefer to buy a PPL product with a PDO/PGI brand & GI2 & 0.952 & 9.471 \\
\hline & & $\begin{array}{l}\text { I feel more guaranteed when the PPL has a PDO/PGI } \\
\text { label too }\end{array}$ & GI3 & 0.993 & 9.637 \\
\hline \multirow{5}{*}{$\begin{array}{l}\text { adapted from } \\
\text { Jackson (1976) }\end{array}$} & \multirow{5}{*}{ Conformism (CON) } & I worry about what people thinking of me & CON1 & 0.865 & n.d. \\
\hline & & I tend to conform my opinion to that of others & $\mathrm{CON} 2$ & 0.891 & 24.076 \\
\hline & & I need others approval & CON3 & 0.933 & 27.039 \\
\hline & & I try to be unique in the eyes of others & CON4 & 0.881 & 19.327 \\
\hline & & I do what others do & CON5 & 0.854 & 18.939 \\
\hline \multirow{5}{*}{$\begin{array}{l}\text { adapted from Van der } \\
\text { Merwe et al. (2014) }\end{array}$} & \multirow{5}{*}{$\begin{array}{l}\text { Label Consciousness } \\
\text { (LAB) }\end{array}$} & $\begin{array}{l}\text { I read the ingredients list on the packaging of the } \\
\text { products I purchase. }\end{array}$ & LAB1 & 0.785 & n.d. \\
\hline & & $\begin{array}{l}\text { I am informed about nutritional aspects of the products } \\
\text { I purchase. }\end{array}$ & LAB2 & 0.781 & 16.146 \\
\hline & & I always read the labels: I want to know what I eat & LAB3 & 0.840 & 15.583 \\
\hline & & $\begin{array}{l}\text { I compare food labels and I choose those with the best } \\
\text { nutritional values. }\end{array}$ & LAB4 & 0.953 & 14.123 \\
\hline & & $\begin{array}{l}\text { I usually compare the information on the label before } \\
\text { choosing one product rather than another. }\end{array}$ & LAB5 & 0.964 & 15.481 \\
\hline \multirow{3}{*}{$\begin{array}{l}\text { adapted from } \\
\text { Baltas (1997) }\end{array}$} & \multirow{3}{*}{ PPL Familiarity } & $\begin{array}{l}\text { I consider myself an expert in purchasing PPL brand } \\
\text { products }\end{array}$ & PPLF1 & 0.934 & n.d. \\
\hline & & I consider myself acknowledged about PPL products & PPLF2 & 0.977 & 39.133 \\
\hline & & I am familiar with PPL branded products & PPLF3 & 0.987 & 36.409 \\
\hline
\end{tabular}

In accordance with previous studies, gender and age were included as control variables, as they resulted as being related to the intention to buy PLs (Dhar \& Hoch, 1997; Richardson et al., 1996).

\subsection{Participant Characteristics}

Using a convenience and non-probability sampling technique (Jayakrishnan et al., 2016) a total of 211 structured usable questionnaires were collected.

The sample was mainly composed by females $(81.9 \%)$ and by adults and mature people, living in heterogeneous families (see Table 2).

Table 2. The sample: demographics

\begin{tabular}{lllc}
\hline Age Class & $(\%)$ & Family composition & $(\%)$ \\
\hline $18-24$ & 7.6 & Single & 8.6 \\
$25-35$ & 13.8 & Couple & 26.7 \\
$35-50$ & 34.3 & Three people & 19.0 \\
$51-65$ & 27.2 & Four people & 27.6 \\
$>65$ & 17.1 & Five or more people & 18.1 \\
\hline
\end{tabular}




\subsection{Methodology}

To assess the theoretical hypotheses, a two-step approach was employed (Anderson \& Gerbing, 1988): the uni-dimensionality and convergent validity of the constructs were verified through a confirmatory factor analysis (CFA) and then a structural equation model was tested with the Maximum Likelihood method (SEM). Data was processed through the software Lisrel 8.80 (Jöreskog \& Sörbom, 2006). Structural equation models have been extensively used in the PL literature as they allow to measure direct and indirect effects between constructs (e.g. Van der Merwe et al., 2014; Jayakrishnan et al., 2016). Accordingly, to "test the causal relationship" (Laroche et al., 1996, p. 118) among the PPL quality, geographical indication, conformism, label consciousness and PPL familiarity and the intention to buy PPL products the structural equation modelling procedure was used.

\subsection{Confirmatory Factor Analysis}

Results of the factor analysis confirmed that all the items are significantly (t-values $>9$ ) and substantially (factor loading $\geq 0.775$ ) loaded onto the expected latent constructs (Table 1), confirming the convergent validity of the measures employed (Hu \& Bentler, 1999). Hence, all the 24 items showed a high item-total correlation evidencing their suitability to assess the examined constructs.

\subsubsection{Validity of the Measurement Model}

The Average Variance Extracted (AVE) and the Composite Reliability (CR) evaluate the convergent validity of the investigated constructs (Table 3), displaying adequate indexes in line with the literature suggestions (Fornell \& Larcker, 1981; Steenkamp \& van Trijp, 1991). As each construct resulted to share more variance with its own measures than with other constructs, the discriminant validity was assessed too for all the seven investigated constructs (Table 3): the measurement model displays an appropriate internal validity.

Table 3. Convergent and discriminant validity and correlation matrix

\begin{tabular}{lccrcccccc}
\hline Constructs & AVE & CR & & & & & & \\
\hline Intention to buy PPL & 0.862 & 0.967 & $\mathbf{0 . 9 2 9}$ & & & & & & \\
Attitude towards PPL & 0.777 & 0.913 & 0.658 & $\mathbf{0 . 8 8 1}$ & & & & & \\
PPL Quality & 0.820 & 0.901 & 0.581 & 0.736 & $\mathbf{0 . 9 0 5}$ & & & \\
Geographical Indication & 0.831 & 0.936 & 0.295 & 0.347 & 0.327 & $\mathbf{0 . 9 1 2}$ & & \\
Conformism & 0.784 & 0.948 & -0.185 & -0.218 & -0.123 & -0.115 & $\mathbf{0 . 8 8 5}$ & & \\
Label Consciousness & 0.754 & 0.938 & 0.165 & 0.235 & 0.185 & 0.139 & 0.198 & $\mathbf{0 . 8 6 8}$ & \\
PPL Familiarity & 0.933 & 0.977 & 0.752 & 0.642 & 0.642 & 0.353 & -0.234 & 0.175 & $\mathbf{0 . 9 6 6}$ \\
\hline
\end{tabular}

The structural model evidences a good overall fit. Even if the Satorra and Bentler chi-square $\chi_{(\mathrm{SB})}^{2}(271)=$ 448.362, $\mathrm{p}<0.00$ and the Close-Fit RMSEA ( $\mathrm{p}$-value $=0.015$ ) are significant, as the postulated model does not mirror the pattern of covariance enclosed within the raw data, the $\chi^{2} / \mathrm{df}$ index (1.653) confirms the goodness of the model fit. No substantial problems with residuals are present, as evidenced by the small value of the Standardized Root Mean Square Residual (SRMR $=0.0516$ ). The model presents an overall good fit as indicated by the Goodness of Fit Index value $(\mathrm{GFI}=0.818)$ and by the incremental fit measurements greater than 0.95 (NFI $=0.951 ; \mathrm{CFI}=0.978)$.

\section{Results}

The structural model (Fig. 2) shows a significant predictive ability for both attitude towards PPLs and consumers' intention to buy PPLs. In fact, the $\mathrm{R}^{2}$ value of 0.62 demonstrates that the combined effect of attitude towards PPLs and PPLs familiarity explain a high amount of variance of consumers' intention to buy PPLs. Similarly, perceived quality and PPL familiarity, combined with Geographical Indication, label consciousness and consumers' conformism, all together explain the $61.2 \%$ of the variance of attitude towards PPL products $\left(\mathrm{R}_{(\text {PPLA) }}^{2}=0.61\right)$.

PPLs perceived quality results as the core antecedent of attitude towards PPLs, confirming our first hypothesis (H1: $\beta=0.531, p<0.01$ ). The GI label does not exert any significant effect on PPLA; so, our second hypothesis is rejected $(\mathrm{H} 2: \beta=0.063, p=0.161)$. Conversely, the interest about the information reported on the label of PPL products (label consciousness) has a significant and positive effect on PPLA: so, our fourth hypothesis is confirmed (H4: $\beta=0.109, p=0.02$ ). Conversely, the idea to conform to others opinions and actions seems to have a significant but negative effect on PPL attitude, as follows (H3: $\beta=-0.112, p=0.02)$. PPL familiarity has a 
positive and significant effect on both intention to buy PPL products and attitude towards them (H5a: $\beta=0.233$, $\mathrm{p}<0.01 ; \mathrm{H} 5 \mathrm{~b}: \beta=0.577, \mathrm{p}<0.01)$. Lastly, attitude towards PPLs exerts a positive and significant effect on consumers' intention to buy PPLs, confirming the sixth hypothesis (H6: $\beta=0.300, p<0.01$ ). Further, respondents' gender and age were added as control variables in the empirical model. As shown in the Figure 2, no significant effect was found for both variables. Thus, we can conclude that there is not a particular demographic characteristic that identifies shoppers more willing to buy PPL products.

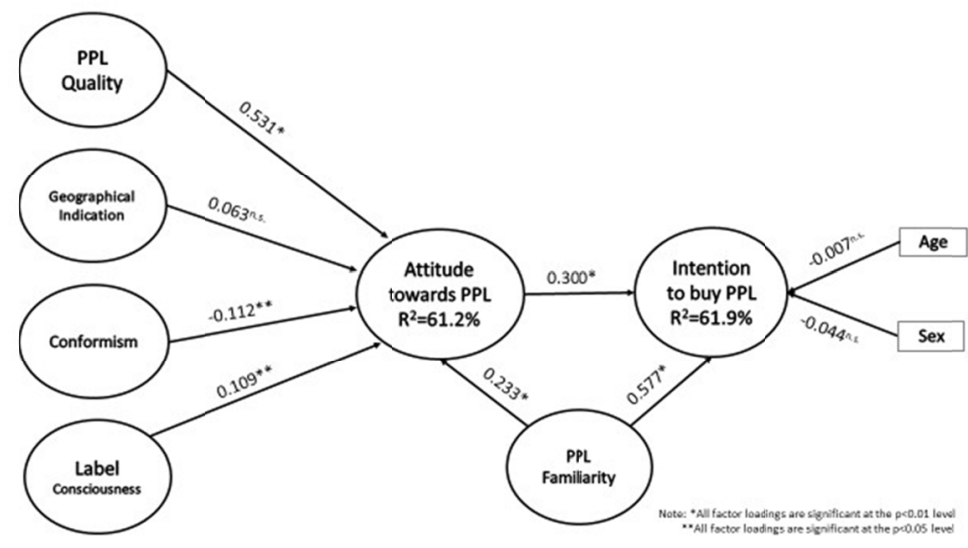

Figure 2. Results for the structural model

\subsection{Mediation Analysis}

To measure the path and the significance of the indirect effects of PPLs perceived quality, geographical indication, consumers' conformism, label consciousness and PPL familiarity on intention to buy PPLs by the means of consumers' attitude towards PPLs a Sobel test was executed. Findings evidenced that when the PPL product is perceived as a quality product, consumers are more willing to buy it (PPLQ $\rightarrow$ PPLA $\rightarrow$ PPLI: $\beta=0.270, p<0.001$ ). Albeit with a less significant effect, also the informative contribution deriving from PPLs labels can be considered as an indirect driver of intention to purchase PPLs (Label $\rightarrow$ PPLA $\rightarrow$ PPLI: $\beta=0.039$, $\mathrm{p}=0.080$ ). Conversely, consumers' conformism exerts a negative indirect effect on intention to buy a PPL product (Conformism $\rightarrow$ PPLA $\rightarrow$ PPLI: $\beta=-0.035, p=0.051$ ). No significant effect was found concerning the indirect effects of the GI certification and PPL familiarity on intention to buy a PPL product.

\section{Discussion}

The increasing value gained by the PLs Premium tier as tool to improve the retailer's reputation, credibility and distinctiveness, makes PPLs an interesting topic for scholars and retail managers. Within this research context, our results contribute to the literature on retail private labels identifying the effect of some main drivers of consumers' attitudes and intentions towards PPLs. Our results may also support retailers in better defining the underpinnings of their PLs market strategy: in order to properly positioning their PPL, they should be aware of the antecedents that are negatively or positively impacting on consumers' attitudes and intentions. To this regards, PPLs perceived quality resulted to be the main direct antecedent of attitude towards PPLs and the indirect driver for intention to buy PPLs. Consequently, retailers should strengthen the efforts placed on the process to improve their quality, establishing high-quality standards and quality controls with their PPLs suppliers. Even if this result confirms extant literature and was somewhat expected, an interesting and original aspect emerging from our work concerns the increasing consumers' interest for product labels in relation to consumers' attitude and intentions toward PPLs: product labels provide information about the ingredients and the nutritional values of products, among others, and consumers more inclined to read them tend to develop a more positive attitude and a higher intention to purchase PPLs. So, retailers should implement communication strategies aimed at stimulating label consciousness if they want to develop a higher penetration rate within PPLs users and extend the target market. Interesting is also the result concerning the no significant relationship between Geographical Indication and PPLs buying intentions. In fact, in opposition to our expectations, although retailers are putting great efforts to introduce GI certified items in the Premium branded assortment, consumers do no seems to directly associate the GI label to Premium Private Label products. Accordingly, retailers should reduce the efforts in communicating the extension of PPL assortments with further GI labelled products to their customers, even if this statement should be better supported in further studies, analysing with more detail the effects of the 
association of the GI label with the PPL label. Finally, our findings confirm that, also in the context of a premium private label, brand familiarity plays a key role in supporting the consumer buying process with a positive and direct impact on both attitude and intention to buy PPL products.

Despite several contributions made by this study, some limitations are present too. Interviewees were asked to evaluate the PPL in general, without referring to a specific product category. But, as extant literature on PLs found differences in consumer behavior when the merchandise varies, future researches should distinguish or compare PPLs in different food categories in order to verify the possible presence of common consumers' patterns. Moreover, other drivers not included in this analysis might impact on customers' attitudes and intentions; so, the model could be extended in future studies. Last but not least, this work was purposed in Italy and in a sole retailer; comparing the same model in a different national context and/or for different retailers would lead to a better understanding of PPLs consumer behaviour.

\section{Acknowledgments}

Even if authors contributed equally to the study, Elisa Martinelli devoted greater attention to the theoretical background and hypotheses and discussion (paragraphs 1, 2, 3 and 6), while Francesca De Canio tested the empirical model and developed the results (paragraphs 4 and 5).

\section{References}

Aaker, D. A. \& Keller, K. L. (1990). Consumer Evaluations of Brand Extensions. Journal of Marketing, 54(1), 27-41. https://doi.org/10.2307/1252171

Ajzen, I. \& Fishbein, M. (1980). Understanding Attitudes and Predicting Social Behavior. Englewood Cliffs, NJ: Prentice-Hall.

Ajzen, I. (1991). The Theory of Planned Behavior. Organizational Behavior and Human Decision Processes, 50(2), 179-211. https://doi.org/10.1016/0749-5978(91)90020-T

Alba, J.W. \& Hutchinson, J.W. (1987). Dimension of consumer expertise. Journal of Consumer Research, 13(4), 411-453. http://dx.doi.org/10.1086/209080

Anderson, Jc. \& Gerbing, Dw. (1988). Structural Equation Modeling in Practice: A Review and Recommended Two-Step Approach. Psychological Bulletin, 103(3), 411-23. https://doi.org/0033-2909/88/\$00.75

Baltas G. (1997). Determinants of store brand choice: a behavioral analysis. Journal of Product \& Brand Management, 6(5), 315-324. https://doi.org/10.1108/10610429710179480

Bazoche, P., Giraud-Héraud, E., \& Soler, L.G. (2005). Premium Private Labels, Supply Contracts, Market Segmentation, and Spot Prices. Journal of Agricultural \& Food Industrial Organization, 3(1), 1-30. https://doi.org/10.2202/1542-0485.1087

Berger, I. E., Ratchford, B. T. \& Haines, G. Jr. (1994). Subjective product knowledge as a moderator of the relationship between attitudes and purchase intentions for a durable product, Journal of Economic Psychology, 15(2), 301-314. https://doi.org/10.1016/0167-4870(94)90006-X

Bhat, S. \& Reddy, S. K. (2001). The impact of parent brand attribute associations and effect on brand extension evaluation. Journal of Business Research, 53(3), 111-122. https://doi.org/10.1016/S0148-2963(99)00115-0

Binninger, A. S. (2008). Exploring the Relationships Between Retail Brands and Consumer Store loyalty. International Journal of Retail \& Distribution Management, 36(2), 94-110. https://doi.org/10.1108/09590550810853057

Borsa Italiana (2019). Le Private Label conquistano il mercato. Retrieved from https://www.borsaitaliana.it/notizie/food-finance/lifestyle/privatelabel.htm

Boutaud, J. J., Becuţ, A., \& Marinescu, A. (2016). Food and culture. Cultural patterns and practices related to food in everyday life. Introduction. International Review of Social Research, 6(1), 1-3. http://dx.doi.org/10.1515/irsr-2016-0001

Burton, S., Lichtenstein, D. R., Netemeyer, R. G., \& Garretson, J. A. (1998). A scale for measuring attitude toward private label products and an examination of its psychological and behavioral correlates. Journal of the Academy of Marketing Science, 26(4), 293-306. http://dx.doi.org/10.1177/0092070398264003

Calvo-Porral, C., \& Levy-Mangin, J. P. (2016). Food private label brands: the role of consumer trust on loyalty and purchase intention. British Food Journal, 118(3), 679-696. https://doi.org/10.1108/BFJ-08-2015-0299

Campbell, M. C., \& Keller, K. L. (2002). Brand familiarity and advertising repetition effects. Journal of 
Consumer Research, 30(2), 292-304. http://dx.doi.org/10.1086/376800

DelVecchio, D. (2001). Consumer perceptions of private label quality: the role of product category characteristics and consumer use of heuristics. Journal of Retailing and Consumer Services, 8(5), 239-249. https://doi.org/10.1016/S0969-6989(00)00030-8

Dhar, S. K., \& Hoch, S. J. (1997). Why store brand penetration varies by retailer. Marketing Science, 16(3), 208-227. https://doi.org/10.1287/mksc.16.3.208

Dick, A.S., Jain A.K., \& Richardson P. (1996). How consumers evaluate store brands. Journal of Product \& Brand Management, 5(2), 19-28. https://doi.org/10.1108/10610429610119405

Dimara, E., \& Skuras, D. (2005). Consumer demand for informative labeling of quality food and drink products: a European Union case study. Journal of Consumer Marketing, 22(2), 90-100. https://doi.org/10.1108/07363760510589253

European Commission (2019). Retrieved from https://ec.europa.eu/info/food-farming-fisheries/food-safety-and-quality/certification/quality-labels/qualityschemes-explained\#aims

Feetham, P., \& Gendall, P. (2013). The Positioning of premium private label brands. Market \& Social Research, 21(1), 28-37.

Fornell, C., \& Larcker, D. F. (1981). Evaluating structural equation models with unobservable variables and measurement error. Journal of Marketing Research, 18(1), 39-50. https://psycnet.apa.org/doi/10.2307/3151312

Fotopoulos, C. \& Krystallis, A. (2003). Quality labels as a marketing advantage. The case of the "PDO Zagora" apples in the Greek market. European Journal of Marketing, 37(10), 1350-1374. https://doi.org/10.1108/03090560310487149

Geyskens, I., Gielens, K., \& Gijsbrechts, E. (2010). Proliferating private-label portfolios: How introducing economy and premium private labels influences brand choice. Journal of Marketing Research, 47(5), 791-807. http://journals.ama.org/doi/abs/10.1509/jmkr.47.5.791

González-Miere, C. G., Martin, A. M., \& Gutierrez, J. A. T. (2006). Influence of perceived risk on store brand proneness. International Journal of Retail \& Distribution Management, 34(10), 761-772. https://doi.org/10.1108/09590550610691347

Grewal, D., Krishnan, R., Baker, J., \& Borin, N. (1998). The effect of store name, brand name and price discounts on consumers' evaluations and purchase intentions. Journal of Retailing, 74(3), 331-352. https://doi.org/10.1016/S0022-4359(99)80099-2

Grønhaug, K., Hem, L., \& Lines, R. (2002). Exploring the impact of product category risk and consumer knowledge in brand extensions. Journal of Brand Management, 9(6). 463-476. https://doi.org/10.1057/palgrave.bm.2540093

Hoch, S. J., \& Banerji, S. (1993). When Do Private Labels Succeed? Sloan Management Review, 34(Summer), 57-67. https://search.proquest.com/docview/1302972663?accountid $=1658$

Hu, L.-T., \& Bentler, P.M. (1999). Cutoff criteria for fit indexes in covariance structure analysis: Conventional criteria versus new alternatives. Structural Equation Modeling: A Multidisciplinary Journal, 6(1), 1-55. https://doi.org/10.1080/10705519909540118

Huang, Y., \& Huddleston, P. (2009). Retailer premium own-brands: creating customer loyalty through own-brand products advantage. International Journal of Retail \& Distribution Management, 37(11), 975-992. https://doi.org/10.1108/09590550910999389

IRI (2018). XIV Rapporto sull'evoluzione dei prodotti a MARCA del distributore in Italia, Adem Lab University of Parma

Jackson, D. N. (1976). Jackson Personality Inventory Manual. Goshen, N.Y.: Reserch Pshychologists Press.

Janssen, M., \& Hamm, U. (2014). Governmental and private certification labels for organic food: Consumer attitudes and preferences in Germany. Food Policy, 49, 437-448. https://doi.org/10.1016/j.foodpol.2014.05.011

Jayakrishnan S., Chikhalkar, R., \& Chaudhuri, R. (2016). Understanding the Role of Consumer Factors and Store Factors in Private Label Purchase. International Journal of Business and Management, 11(7), 
223-236. https://doi.org/10.5539/ijbm.v11n7p223

Jöreskog, K. G., \& Sörbom, D. (2006). LISREL 8.80 for Windows. Lincolnwood, IL: Scientific Software International.

Kastanakis, M. N., \& Balabanis, G. (2012). Between the mass and the class: Antecedents of the "bandwagon" luxury consumption behavior. Journal of Business Research, 65(10), 1399-1407. http://dx.doi.org/10.1016/j.jbusres.2011.10.005

Kumar, N., \& Steenkamp, J. B. E. M. (2007). Private Label Strategy. Cambridge, MA: Harvard Business School Press.

Lamey, L., Deleersnyder, B., Dekimpe, M. G., \& Steenkamp, J. B. E. (2007). How business cycles contribute to private-label success: Evidence from the United States and Europe. Journal of Marketing, 71(1), 1-15. http://journals.ama.org/doi/10.1509/jmkg.71.1.1

Laroche, M., Kim, C., \& Zhou, L. (1996). Brand familiarity and confidence as determinants of purchase intention: An empirical test in a multiple brand context. Journal of Business Research, 37(2), 115-120. http://dx.doi.org/10.1016/0148-2963(96)00056-2

Lascu, D. N., \& Zinkhan, G. (1999). Consumer conformity: review and applications for marketing theory and practice. Journal of Marketing Theory and Practice, 7(3), 1-12. https://doi.org/10.1080/10696679.1999.11501836

Martinelli, E., De Canio, F. \& Marchi, G. (2019). Premium Private Labels (PPLs): from food products to concept stores, in Byrom J., Medway D. (Eds), Case Studies in Food Retailing and Distribution, Elsevier. http://dx.doi.org/10.1016\%2FB978-0-08-102037-1.00018-9.

Martinelli, E., De Canio, F., Marchi, G., \& Nardin, G. (2017). Premium Private Labels and PDO/PGI Products: Effects on Customer Loyalty. In Martínez-López F.J., Gázquez-Abad J.C., Ailawadi K. L., Yagüe-Guillén M.J. (Eds.), Advances in National Brand and Private Label Marketing (pp. 65-72). http://dx.doi.org/10.1007/978-3-319-92084-9_6

MIPAAF. (2019). Elenco dei prodotti DOP, IGP e STG (aggiornamento al 17.04.2019). Retrieved from https://www.politicheagricole.it/flex/cm/pages/ServeBLOB.php/L/IT/IDPagina/2090.

Morris, D. (1979). The strategy of own brands. European Journal of Marketing, 13(2), 59-78. https://doi.org/10.1108/EUM0000000004930

Morrone, D., \& Schena, R. (2019). The Evolution of Private Labels in Food Proposals: The Case of the Top Four Italian Retailers and the Purchase Propensity of Consumers. International Journal of Business and Management, 14(3), 69-77. https://doi.org/10.5539/ijbm.v14n3p69

Pan Y., \& Zinkhan, G. M. (2006). Determinants of retail patronage: a meta-analytical perspective. Journal of Retailing, 82(3), 229-24. https://doi.org/10.1016/j.jretai.2005.11.008

Parrott, N., Wilson, N., \& Murdoch, J. (2002). Spatializing quality: regional protection and the alternative geography of food. European Urban and Regional Studies, 9(3), 241-61. https://doi.org/10.1177\%2F096977640200900304

Pauwels, K., \& Srinivasan, S. (2004). Who benefits from store brand entry? Marketing Science, 23(3), 364-390. https://doi.org/10.1287/mksc.1030.0036

Raju, J. S, Srinivasan, V., \& Lal, R. (1990). The effects of brand loyalty on competitive price promotional strategies, Management Science, 36(3), 276-304. https://doi.org/10.1287/mnsc.36.3.276

Raju, J. S., Sethuraman, R., \& Dhar, S. K. (1995). The introduction and performance of store brands. Management Science, 41(6), 957-978. https://doi.org/10.1287/mnsc.41.6.957

Richardson, P. S., Dick, A. S. \& Jain, A. K. (1994). Extrinsic and intrinsic cue effects on perceptions of store brand quality. Journal of Marketing, 58(4), 28-36. https://doi.org/10.1177/002224299405800403.

Richardson, P. S., Jain, A., \& Dick, A. (1996). Household store brand proneness: a framework. Journal of Retailing, 72(2), 159-185. https://doi.org/10.1016/S0022-4359(96)90012-3

Sayman, S., \& Raju, J. S. (2004). How category characteristics affect the number of store brands offered by the retailer: A model and empirical analysis. Journal of Retailing, 80(4), 279-287. https://doi.org/10.1016/j.jretai.2004.10.004

Sethuraman, R., \& Gielens, K. (2014). Determinants of Store Brand Share. Journal of Retailing, 90(2), 141-153. 
https://doi.org/10.1016/j.jretai.2014.04.002

Sethuraman, R. (2009). Assessing the external validity of analytical results from national brand and store brand competition models, Marketing Science, 28(4), 759-781. http://dx.doi.org/10.1287/mksc.1080.0455

Sheau-Fen, Y., Leong, S. M., \& Wee, Y. G. (2012). Store brand proneness: effects of perceived risk, quality and familiarity. Australasian Marketing Journal, 20(1), 48-58. https://doi.org/10.1016/j.ausmj.2011.10.014

Soberman, D. A., \& Parker, P. M. (2006). The economics of quality-equivalent store brands. International Journal of Research in Marketing, 23(2), 125-139. https://doi.org/10.1016/j.ijresmar.2005.09.008

Steenkamp, J. B. E. M., Van Heerde, H., \& Geyskens, I. (2010). What makes consumers willing to pay a price premium for national brands over private labels? Journal of Marketing Research, 47(6), 1011-1024. https://doi.org/10.1509/jmkr.47.6.1011

Steenkamp, J. B., \& van Trijp, H. (1991). The use of lisrel in validating marketing constructs. International Journal of Research in Marketing, 8(4), 283-299. https://doi.org/10.1016/0167-8116(91)90027-5

Ter Braak, A., Geyskens, I., \& Dekimpe, M. G. (2014). Why Premium Private Label Presence Varies by Category. Journal of Retailing, 90(2), 125-140. https://doi.org10.1016/j.jretai.2014.01.003

Ter Braak, A., Dekimpe, M. G., \& Geyskens, I. (2013). Retailer private-label margins: The role of supplier and quality-tier differentiation. Journal of Marketing, 77(4), 86-103. https://doi.org/10.1509/jm.11.0566

Teuber, R. (2011). Consumers' and producers' expectations towards geographical indications: Empirical evidence for a German case study. British Food Journal, 113(7), 900-918. https://doi.org/10.1108/00070701111148423

The European House - Ambrosetti. (2018). La Marca del Distributore: il Valore e il Ruolo per il Sistema-Paese, The European House - Ambrosetti.

Van der Merwe, D., Bosman, M., \& Ellis, S. (2014). Consumers' opinions and use of food labels: Results from an urban- rural hybrid area in South Africa. Food Research International, 63, 100-107. https://doi.org/10.1016/j.foodres.2014.03.032

Van Ittersum, K., Meulenberg, M. T. G., van Trijp H. C. M., \& Candel, M. J. J. M. (2007). Consumers' Appreciation of Regional Certification Labels: A PanEuropean Study. Journal of Agricultural Economics, 58(1), 1-23. https://doi.org/10.1111/j.1477-9552.2007.00080.x

Walsh, G., \& Mitchell, V. W. (2010). Consumers' intention to buy private label brands revisited. Journal of General Management, 35(3), 3-24. https://doi.org/10.1177\%2F030630701003500302

Ward, J. C., Bitner, M. J., \& Barnes, J. (1992). Measuring the prototypicality and meaning of retail environments. Journal of Retailing, 68(2), 194-220.

Wu, P. C., Yeh, G. Y. Y., \& Hsiao, C. R. (2011). The effect of store image and service quality on brand image and purchase intention for private label brands. Australasian Marketing Journal, 19(1), 30-39. https://doi.org/10.1016/j.ausmj.2010.11.001

Zajonc, R. B., \& Markus, H. (1982). Affective and cognitive factors in preferences. Journal of consumer research, 9(2), 123-131.

Zeithaml, V. A., Berry, L. L., \& Parasuraman, A. (1996). The behavioral consequences of service quality. Journal of Marketing, 60(April), 31-46. https://doi.org/10.2307/1251929

\section{Copyrights}

Copyright for this article is retained by the author(s), with first publication rights granted to the journal.

This is an open-access article distributed under the terms and conditions of the Creative Commons Attribution license (http://creativecommons.org/licenses/by/4.0/). 